\title{
Learning Styles and Academic Achievement among Form Three Living Integrated Skills Students
}

\author{
Mustafa Rehman Khan* \\ Universiti Pendidikan Sultan Idris, 35900 Tanjong Malim, Perak, Malaysia
}

\begin{abstract}
Learning styles indicate a students' preference for learning methods and therefore are necessary information to guide teachers' instruction. This study is aimed to determine the relationship between learning styles and academic achievement of Form Three students in their Living Integrated Skills subject. This study was participated by 372 respondents selected using purposive sampling from six secondary schools in Sabah, Malaysia. Data was collected using a research questionnaire in survey research and analyzed with IBM SPSS 23.0 using both descriptive and inferential statistical analyses. Findings of the study showed that pragmatist and theorist learning styles are the dominant learning styles while activist is the least preferred learning style. It was found that learning styles i.e. activist $(t=-0.412 ; p=0.681)$, reflective $(t=-1.457 ; p=0.146)$, theorist $(\mathrm{t}=0.890 ; \mathrm{p}=0.374)$ and pragmatist $(\mathrm{t}=-0.537 ; \mathrm{p}=0.592)$ did not differ significantly based on gender but learning styles i.e activist $(t=7.412, p=0.000)$, reflective $(t=9.461, p=0.000)$, theorist $(t$ $=9.080, \mathrm{p}=0.000)$ and pragmatist $(\mathrm{t}=8.615, \mathrm{p}=0.000)$ was significantly different between high and low academic achievers. The higher achievers were pragmatic and activist while the lower achievers were reflective and theorists. This study also showed that learning styles i.e. activist $(\mathrm{r}=$ 0.395, $\mathrm{p}=0.000)$, reflective $(\mathrm{r}=0.476, \mathrm{p}=0.000)$, theorist $(\mathrm{r}=0.492, \mathrm{p}=0.000)$ and pragmatist $(\mathrm{r}=$ $0.471, \mathrm{p}=0.000$ ) were significantly correlated with academic achievement. Theorist learning style has the strongest correlation with academic achievement followed by reflective and pragmatist and the weakest learning style is activist. This study implied that other factors like a classroom environment, instructional delivery, and students' self-efficacy should be investigated in future studies to explain the academic achievement of the students. This study supported the notion that learning styles are important to facilitate teachers in planning and implementing the lesson and for students to develop meta-cognitive ability to learn with the best style suited to them.
\end{abstract}

Keywords: learning styles; academic achievement; form 3 students; education; Malaysia

\section{INTRODUCTION}

Education in Malaysia has become one of the most important tools to drive national development especially in the 21st century which is ever-challenging (Warner \& Kaur, 2017). The Malaysian Ministry of Education (MOE) has prepared the Malaysian Education blueprint for the period year 2013 to 2025 as guidelines for transform education program to empower the nation's human capital with expertise and skills of the 21st century and be among the top global payers (Ministry of Education Malaysia, 2013). The educational transformation embedded in the Malaysian education development plan (MEDP) has outlined the need to equip each student with the learning experience that can lead them to become competent workers which are appropriate with the needs and demands of the 21st-century workforce. Among others, the MEDP has presented five aspirations of the national education system to be attained which are access, quality, equity, and efficiency which serves as the benchmark to all organisations and education implementor so that a high-quality education with an 
international status can be attained (Ministry of Education Malaysia, 2013). In a globalised world, the creation of intellectual, social, and human capital in Malaysia becomes critically important for the country to be competitive and the student is the future human capital of the nation $(\mathrm{Ng}$ et. al., 2014; Renganathan, 2021). MEDP has also stated 11 paradigm shifts that need to be realised to ensure that the national education system has high quality (Ministry of Education, 2013). Through the implementation of educational policies and programs based on these paradigm shifts, the output of competitive students can be maximised and at the same time, the teachers also enhance their quality in carrying out the teaching and learning process at school (Dinham et al., 2020). In other words, two main interests in the MEDP are the quality of the human capital, i.e. the students that are produced, and the quality of teaching and learning provided by the teachers in the educational system.

The provision of a high-quality education has become the main consideration in every country including Malaysia (Singh \& Jamil, 2021). Kimani et al. (2013) stated that education aims to equip its people with the values, skills, and knowledge to reinvent the society that is aligned to the current needs and demands. The success of an educational institution normally can be measured by the performance of the students, either in the academic or non-academic fields (Mphale \& Mhlauli, 2014). The measurement of academic achievement has been considered as the symbol of school success which can be traced since the Victorian era (Bell, 2018). The academic achievement of students in school has been taken as a yardstick to show the success and performance of the school itself (Mphale \& Mhlauli, 2014). Therefore, this has led much attention to the students' academic performance and regarded as relevant up to now and has become the main concern in this study.

Another aspect that is often associated with 21st-century education is the transition from teacher-centred learning to student-centred learning (Boholano, 2017). Therefore, teachers are required to align the teaching and learning approaches to give the best learning experience to the students. Hence, one of the needs in planning the teaching and learning activities in the classroom is to accommodate the learning styles of the students with the instructions provided by teachers. Consequently, this has led the interest of this study to the situation where the learning styles of students and their relationship with their academic performance are assessed.

\section{BACKGROUND OF STUDY}

Malaysian Education Development Plan (MEDP) had outlined six characteristics of an internationally acclaimed educational institution that can compete successfully at the global level, which are: (i) focus on the skills of the 21stcentury learners; (ii) the relevancy of the applied curriculum; (iii) informed assessment; (iv) focus on social and emotional relationship; (v) focus on creative and innovative culture; and (vi) access $24 / 7$ to equipment and resources (Ministry of Education, 2013). Most importantly, the students need to be equipped with six characteristics to ensure that they are globally competitive which are: knowledge, thinking skills, leading skills, dual language skills, ethical and spiritual and have a national identity (Ministry of Education Malaysia, 2013). The demand for quality is implied in the MEDP and thus, imploring teachers as the curriculum implementer in schools to ensure that the teaching and learning process experienced by the students can bring about excellent academic performance (Davrajoo \& Letchumanan, 2019), not only in critical subjects such as Malay language, English, Mathematics, and Science but also for all other subjects.

The Living Integrated Skills (LIS) is one of the subjects offered to all students in the lower secondary level. LIS is one of the compulsory subjects taken by students from Form 1 to Form 3 and this subject encompasses technology and entrepreneurship. The syllabus for LIS includes two main learning components which is the main component, Reka Bentuk dan Teknologi (Design and Technology), and a selection of other components by the student which can be either Kemahiran Teknikal (Technical Skills), Ekonomi Rumah Tangga (Home Economy), Pertanian (Agriculture) and Perdagangan dan Keusahawanan (Commerce and Entrepreneurship) (Ministry of Education, 2002).

The subject emphasised more on practical learning to provide the students with the skills for functional purposes so that they can manage their lives in a technological environment (Kon et al., 2012). The emphasis of the education system in this country on science, technology, 
engineering, and mathematics (STEM) in the last few decades implied the relevancy and importance of the LIS subject for the academic development of the students (Kumar et. al., 2020; Zainuddin et al., 2019). Therefore, the focus on students' academic achievement in this subject is also considered as important to ensure that the learning process that they undergo during the lower secondary school in this subject can enrich their knowledge before they move on to the higher levels.

The presentation of various knowledge and skills in the LIS subject can enhance the students' imagination and creativity whereby the critical thinking skills become one of the main concerns to be assimilated in the minds of the students (Fadzil et al., 2017). Other than that, this subject requires numerous techniques and methods of teaching and learning as it involves both theory and practical (Kon et al., 2012). Thus, the teacher needs to identify the students' learning styles so that they can be aligned to the teaching of the subject and ensures that their academic achievement in the subject is high.

Learning styles can explain the learning behaviour of an individual. The learning styles show how a student learns and what they like to learn using instructional strategies that are aligned to the cognition, context, and learning content (Srivastava \& Shah, 2021). In the 21st century education of today, teachers must be smart to choose the teaching methods and techniques compatible with the students' learning styles (Kruk \& Zawodniak, 2019). Therefore, the teacher needs to identify which learning styles are dominant among the students and then, relate the teaching process and learning environment to ensure a high academic achievement.

Studies that relate learning styles with academic achievement have been done quite a lot and it is not recent. Many studies carried out were done outside of Malaysia (Chermahini et. al., 2013; Akhlaghi et. al., 2018; Kruk \& Zawodniak, 2019; Srivastava \& Shah, 2021) and also in Malaysia (Ang et. al., 2017; Awang et. al., 2017; Davrajoo \& Letchumanan, 2019; Kumar et al., 2020). However, these studies in the Malaysian context were focused on college and university students. Local studies are focusing on secondary schools to investigate the relationship between learning styles and students' academic achievement (Davrajoo \&
Letchumanan, 2019; Hamid et al., 2019) but there were done in general or focusing on other subjects. Studies like Elias et al. (2012) did focus on the relationship between learning styles and academic achievement among Form four students but such studies are scarce. Therefore, this study focuses on the learning styles of Form Three students and the relationship with their academic achievement for the LIS subject.

\section{THEORETICAL FRAMEWORK}

\section{Learning Styles}

Learning is something or an event that is the outcome of using the mind or the cognitive aspect of an individual. Therefore, the term 'learning style' or 'cognitive style' or 'learning strategy' are often misunderstood as having the same meaning but in fact, provides a different meaning in a particular context. According to Allport (1937), cognitive style is the routine way that the individual is used to problem-solving, thinking, perceiving, and recalling while learning styles are used to show the consideration on the application of cognitive style to the learning situation (Riding \& Cheema, 1991). Hence, the concept of learning styles can include several components which are not mutually exclusive.

Cognitive style is the way that different individual shows different ways of dealing with different cognitive tasks while learning style is the way that an individual deal with different learning tasks. Learning strategies, on the other hand, refer to the strategies that are used while studying or learning whereby different strategy is used to deal with different tasks (Frrat et al., 2021). This implies that learning style is more automatic while learning strategies are optional. Learning styles can be regarded as a trait as it is stable for a while but at the same time, it can be seen as an event that can change with the situation (Hartley, 1998).

When learning styles are explained, two most common learning styles models are used. The first one is the Kolb Experiential Learning Model that can be measured using the Learning Styles Inventory. Kolb (1984) stated that there are four-phased in a hypothetical learning cycle. The individual is inclined or finds it easier to deal with learning at one level compared to the others, whereby learning is considered as a 
continuous interactive process. There are four stages in the model which are concrete experiences (CE) which is inclined towards experiential learning, the abstractive conceptualisation (AC) who deals more with conceptual and analytical thinking to obtain comprehension; the active experimentation (AE) of involving in trial-and-error learning actively; and the reflective observation (RO) which relies on further consideration about the job and solution before any tried attempt is done (Srivastava and Shah, 2021).

The four orientations of learning form a two-dimensional bipolar orthogonal learning. The first dimension is prehension that is, to get information based on experience and comprises the two-bipolar orientation of CE-AC. The second dimension is transformation, whereby information processing is used, and this comprises AE-RO. The location in relative of the dimension explains the expressed learning behaviours as convergent, divergent, assimilator and accumulator. A convergent student uses abstractive conceptualisation to drive active experience. His efforts are based on abstract thinking about the task and planned strategies to complete the task successfully.

A divergent individual combines reflective thinking with concrete experience to gain a creative solution. Therefore, divergent individuals tend to be regarded as creative as their inclination is towards considering numerous possible strategies for learning and problem-solving. For an assimilator, more emphasis is given to describing their observation and a liking for abstractive conceptualisation and reflective observation. This, they can refine abstractive theories but are less competent in developing strategies and solutions that can be done. Finally, accommodators are those who are inclined to use active experimentation and concrete experiences. These individuals are keener on hands-on learning. An accommodator tends to act fast and can adapt to various situations (Lynch et al., 1998). Table 1 summarises the learning styles based on Kolb Model.

Besides Kolb's Model, another common learning style model used in education research is the adapted Honey and Mumford (1992) Model from Kolb's Model. The learning styles explained by Honey and Mumford are almost similar to the learning styles of Kolb:

- Activist - active experimentation (Kolb)

- Reflective - reflective observation (Kolb)
- Theorist - abstractive conceptualisation (Kolb)

- Pragmatist - concrete experience (Kolb)

In the context of this study, the Kolb Model of learning styles which were modified by Honey and Mumford is used. Figure 1 shows the similarities of these two models. In general, the learning styles in Kolb's Model are defined using different terms by Honey and Mumford (1992). Kolb (1984) stated that students can use all four learning styles, but some may be inclined to be dominant in one or two traits. Those who are extroverts are mostly activists/pragmatists while introverts are reflectors/theorists.

Table 1. Learning Styles Based on Kolb's Model

\begin{tabular}{|c|c|c|}
\hline $\begin{array}{c}\text { Learning } \\
\text { Styles }\end{array}$ & $\begin{array}{c}\text { Learning } \\
\text { Orientation }\end{array}$ & $\begin{array}{c}\text { Individual's } \\
\text { Characteristics }\end{array}$ \\
\hline Divergent & CE-RO & $\begin{array}{l}\text { a tendency to perceive concrete } \\
\text { information that are clear and } \\
\text { concise, and process } \\
\text { information based on reflective } \\
\text { observation to produce an idea } \\
\text { without practical. }\end{array}$ \\
\hline Convergent & $\mathrm{AC}-\mathrm{AE}$ & $\begin{array}{l}\text { a tendency to perceive abstract } \\
\text { information by making trials } \\
\text { and active exercises. }\end{array}$ \\
\hline Assimilator & $\mathrm{AC}-\mathrm{RO}$ & $\begin{array}{l}\text { a tendency to perceive abstract } \\
\text { information that need in-depth } \\
\text { analysis where information is } \\
\text { processed with reflective } \\
\text { observation. }\end{array}$ \\
\hline Accommodator & $\mathrm{CE}-\mathrm{AE}$ & $\begin{array}{l}\text { a tendency to perceive concrete } \\
\text { information and processing } \\
\text { them with trials and active } \\
\text { exercises. }\end{array}$ \\
\hline
\end{tabular}

Source: Zanariah and Bhasah (2009) 


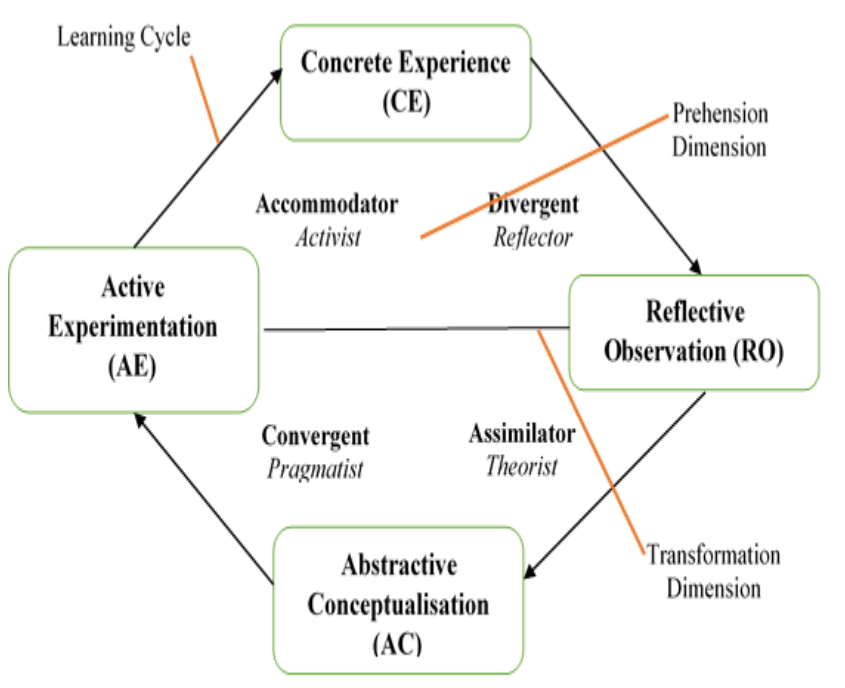

Key:

Bold: Kolb's Learning Styles

Italic: Honey and Mumford's Learning Styles

Figure 1. Kolb Learning Styles and Adaptation of Honey and Mumford Learning Styles

\section{Academic Achievement}

The concept of academic achievement is oftenly used in the education field. Academic achievement is defined as the successful completion of the attainment of academic content and skills through effort (Honicke et al., 2020). Achievement is a behaviour that can be measured using a series of standardised tests to assess the students' proficiency in a subject in the school. According to Kpolovie et al. (2014), students' academic achievement refers to their learning ability and recalling facts as well as being able to communicate verbally or written in an examination situation. Engel (2018) added that academic achievement can be measured through examination that assesses the individual's procedural knowledge like skills, and declarative knowledge such as facts that were learned by the students.

\section{LITERATURE REVIEW}

Learning styles is a concept in the education field that has attracted educators and researchers (Srivastava \& Shah, 2021). Learning styles are the various approaches or ways to learn to ensure that the student learns the best. The perception of learning differences that stemmed from intelligence differences and cognitive ability differences at one point in time has expanded to the current view that these differences in intelligence and cognitive ability are the outcome of various factors; among them are personality characteristics, task difficulty, and learning styles (Yilmaz \& Orhan, 2010). Learning styles are situations that enable a student to perceive, process, store and recall learning contents (Maya et al., 2021). Learning styles identifies a student's inclination or preference towards a certain teaching style at school (Hamid et al., 2019). Therefore, teachers and other teaching teams must play their roles by identifying the learning styles and enhance their teaching quality to ensure students' academic achievement (Tella \& Adeniyi, 2009).

Elias et al. (2012) had investigated the relationship between learning styles and academic achievement among Form 3 students in a technical school for the LIS subject and revealed that teachers must maintain and improve the students' performance by knowing the learning styles of the students. The time students spend on activities such as watching television, browsing the Internet, using social media, attending tuition, and so forth have influenced their academic achievement (Ng et al., 2014).

Daily activities shape the way that the students solve their learning problems. According to Ong et al. (2010), low academic achievement among primary school students in urban areas in Malaysia can be influenced by various factors such as low socio-economy, sibling size, male gender, and history of premature birth. Although these studies did not explore learning styles, it provides strong evidence that academic achievement is a situation that can be influenced by various factors.

Learning styles influence the academic achievement of students. Ang et al. (2017) investigated private college students in Malaysia by using a visual, verbal, active, and sequential learning styles framework. Researchers found that sequential and visual learning styles had a more significant impact on academic achievement compared to active and verbal learning styles (Ang et al., 2017).

Further, researchers indicated a significant relationship between different learning styles with their achievement (Chermahini et al., 2013). Also, they noted a gender difference in the English test performance for convergent and divergent but not for accommodators and assimilators. The study also explains that learning styles need to be considered as predictors of students' academic achievement 
(Chermahini et al., 2013). Additionally, self-concept and logical thinking are significant predictors of academic achievement (Yuksel \& Geban, 2014).

Yuksel and Geban (2014) had highlighted that academic achievement can be influenced by various variables and its determination is required to ensure that the right intervention can be done to improve students' achievement academically. Researchers also mentioned that logical thinking which is a cognitive ability can influence the way an individual learns (Yuksel \& Geban, 2014). Therefore, cognitive learning as a subset of learning styles is an important factor to drive students' academic achievement.

Further Awang et al. (2017) had conducted a study on learning styles' relationship with academic achievement of students in Malaysia polytechnics. Using the VARK (visual, auditory, reading/writing, kinesthetic) learning style, and found that there are no significant relationships between the learning styles and academic achievements of the students. However, Dobson (2010) reported negative significant relationship between achievement in Physiology class using VARK learning styles model.

Homayoni and Abdolahi (2003) investigated the relationship between learning style and female students' achievement in a high school and found a direct correlation between abstractive conceptualisation with academic achievement in mathematics and English. Rahmanpur et al. (2008) investigates the learning styles of students majoring in Engineering found that their styles were different compared to those majoring in Speculative. Felder and Silverman (1988) found that students of the Chemistry field are more active and sensing, verbal and sequential. Dunn et al. (2000) added that the learning styles of males are also different from females. Normally, the boys are more inclined to a kinesthetic and visual learning style while the girls are more auditory type. Hence, different teaching techniques must be utilised in the classroom to accommodate learners with different learning styles, making learning more interesting and relevant to pupils (Payaprom \& Payaprom, 2020).

The academic achievement of students did not differ substantially according to their learning styles (Isa et. al., 2021; Karatas \& Yalin, 2021). Pashler et al. (2008) added that there is no document to explain which learning style is more benefitting the students, but he agreed that the suitability of a student's learning style with his personality characteristics can drive his learning to better performance. Akhlaghi et al. (2018) had investigated the learning styles of dentistry students in Isfahan, Iran. The reading/writing learning styles were more significantly correlated with their academic achievement. However, the employment of multimodal learning styles is more preferable to get the best result in learning (Hernandez et. al., 2020; Kolb, 1984). Therefore, an assessment of achievement should not be based on one measurement only as every learning style has its strengths in a specific task (Damavandi et al., 2011).

Hargadon (2010) also explained that teachers need to pay attention to the differences in learning styles of the students so that these differences can provide an informed decision on the various methods for teaching and assuring students to get the best achievement. Hence, on the basis of literature review this research proposed the following hypotheses:

This research compares the learning styles of the students based on gender and these are represented by the hypothesis statements below.

Ho1a: There is no significant difference in the activist learning style of Form 3 students based on gender

Ho1b: There is no significant difference in the reflective learning style of Form 3 students based on gender

Ho1c: There is no significant difference in the theorist learning style of Form 3 students based on gender

Ho1d: There is no significant difference in the pragmatic learning style of Form 3 students based on gender.

The study also compares the learning styles of students based on the academic achievement of the students in their LIS subject. The following research hypotheses are presented below:

Ho2a: There is no significant difference in the activist learning style of Form 3 students based on academic achievement in the Living Integrated Skills subject 
Ho2b: There is no significant difference in the reflective learning style of Form 3 students based on academic achievement in the Living Integrated Skills subject

Ho2c: There is no significant difference of theorist learning style of Form 3 students based on academic achievement in the Living Integrated Skills subject

Ho2d: There is no significant difference in the pragmatic learning style of Form 3 students based on academic achievement in the Living Integrated Skills subject.

This study also determined the relationship between learning styles and students' academic achievement in the Living Integrated Skills subject. The research hypotheses are presented.

Ho3a: There is no significant relationship between activist learning style and academic achievement in Living Skills of Form 3 students

Ho3b: There is no significant relationship between reflective learning style and academic achievement in Living Skills of Form 3 students

Ho3c: There is no significant relationship between theorist learning style and academic achievement in Living Skills of Form 3 students

Ho3d: There is no significant relationship between pragmatic learning style and academic achievement in Living Skills of Form 3 students

This study identifies the relationship of four learning styles as defined by Honey and Mumford (1992) with the academic achievement of Form 3 students in the Living Integrated Skills subject. Based on the framework presented in Figure 2, the learning styles of activist, reflective, theorist, and pragmatist are independent variables that are related to the dependent variable of students' academic achievement in LIS subject.

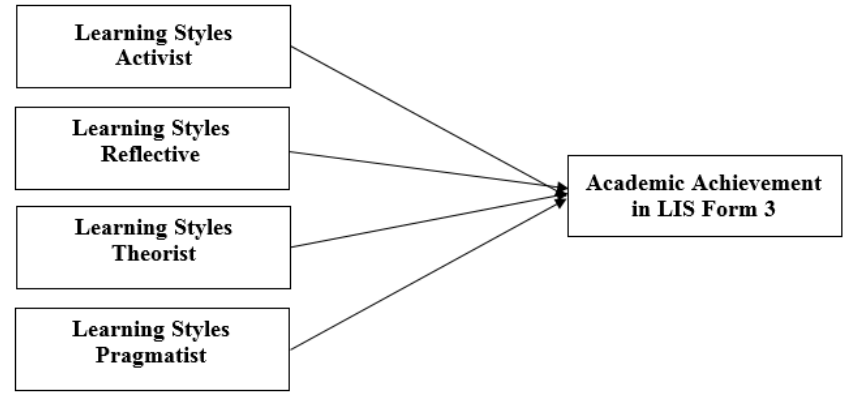

Figure 2. Research Conceptual Framework

\section{METHODOLOGY}

In this quantitative research, data were collected through self-administered questionnaires by conducting a crosssectional survey from the eligible respondents. The population is defined as the Form 3 students in the respective secondary schools that participated in this study. The eligibility criteria for inclusion as the study population are:

-A Form 3 student from any of the six selected schools in Sabah

- A student who took Living Integrated Skills subject from Form 1 to Form 3 in a national secondary school

- Opted for the Commerce and Entrepreneurship Domain

Based on the identified population, a portion of the population was selected using a purposive sampling method. In order to determine the sample size of the study, the sample size calculation formula was used, which based on confidence level at 95\%, the Z score 1.96, and the standard deviation 0.5, while the margin of error 0.05 (Fox \& Mathers, 2007). The computation of the sample size showed that 348 samples required for this study. Thus, a total of 385 responses were collected from selected students. The six schools from where the samples are drawn are located in different districts in Sabah. A total of 372 responses were retained for analysis. Afterwards, data from the questionnaire were keyed into the IBM SPSS version 23.0 for statistical analysis using descriptive and inferential statistics.

The questionnaire comprises of two sections. The first section denotes the demographic characteristics of the students whereby school location, gender, race, place of living and grades in Living Integrated Skills subject were asked with a multiple-choice response. The second section 
pertains to the learning styles of the students. The measurement scale was adapted from the Learning Styles Inventory (Honey \& Mumford, 1992). The items were randomised and does not show the learning types to ensure that the respondents can answer freely based on how they actually act (Duff \& Duffy, 2002). Further, the questionnaire was translated into the Malay language. Therefore, an expert was employed to determine the face and content validity of the questionnaire.

\section{Data Analysis}

The reliability of the measurement scale used in the actual study was determined using the scale analysis to obtain the internal consistency based on Cronbach's alpha. In this study, only one measurement scale which is the Learning Style Inventory using a Likert 4-point scale was used. Findings, as shown in Table 2, indicated that the Cronbach's alpha for activist learning style is 0.818 , while for reflective is 0.987 , for theorist is 0.865 , and for pragmatist is 0.867 . Overall, Cronbach's alpha is 0.949. Therefore, these values showed that each of the dimensions and overall had acceptable internal consistency. Thus, findings from this study have acceptable reliability.

Table 2. Internal Consistency of Learning Styles Inventory in Actual Study

\begin{tabular}{ccc}
\hline Dimension & $\begin{array}{c}\text { Cronbach's } \\
\text { Alpha }\end{array}$ & $\begin{array}{c}\text { Internal } \\
\text { Consistency }\end{array}$ \\
\hline Activist & 0.818 & Good \\
Reflector & 0.987 & Good \\
Theorist & 0.865 & Good \\
Pragmatist & 0.867 & Good \\
Overall & 0.949 & Very Good \\
\hline
\end{tabular}

\section{Demographic Profiles of Students}

The respondents' profiles based on several demographic characteristics are shown in Table 3. The students' profiles in this study were based on their school, gender, race, and place where they live (hostel or non-hostel).
Table 3. Respondents' Demographic Profiles

\begin{tabular}{ccc}
\hline $\begin{array}{l}\text { Demographic } \\
\text { Characteristics }\end{array}$ & Frequency & $\begin{array}{c}\text { Percentage } \\
\text { (\%) }\end{array}$ \\
\hline School & & \\
a. School A & 91 & 24.5 \\
b. School B & 58 & 15.6 \\
c. School C & 63 & 16.9 \\
d. School D & 18 & 4.8 \\
e. School E & 61 & 16.4 \\
f. School F & 81 & 21.8 \\
\hline Gender & & \\
a. Male & 181 & 48.7 \\
b. Female & 191 & 51.3 \\
\hline Race & & \\
a. Malay & 36 & 9.7 \\
b. Kadazandusun & 141 & 37.9 \\
c. Chinese & 17 & 4.6 \\
d. Bajau & 114 & 30.6 \\
e. India & 1 & 0.3 \\
f. Others & 63 & 16.9 \\
\hline Place of Living & & \\
a. Hostel & 54 & 14.5 \\
b. Non-Hostel & 318 & 85.5 \\
\hline
\end{tabular}

\section{Comparison of Learning Styles Based on Gender}

Table 4 shows the result of analysis with independent sample t-test. The result shows that there is no significant difference in the activist $(\mathrm{t}=-0.412 ; \mathrm{p}=0.681)$, reflective $(\mathrm{t}$ $=-1.457 ; \mathrm{p}=0.146)$, theorist $(\mathrm{t}=0.890 ; \mathrm{p}=0.374)$ and pragmatist $(\mathrm{t}=-0.537 ; \mathrm{p}=0.592)$ learning styles between male and female students. Therefore, hypotheses Ho1a, Ho1b, Ho1c and Ho1d are accepted.

Table 4. Comparison of Learning Styles Based on Gender

\begin{tabular}{|c|c|c|c|c|c|c|}
\hline Styles & Gender & $\mathbf{n}$ & Mean & SD & $\mathbf{t}$ & $\mathbf{p}$ \\
\hline \multirow{2}{*}{ Activist } & Male & 181 & 32.25 & 4.66 & \multirow{2}{*}{-0.412} & \multirow{2}{*}{0.681} \\
\hline & Female & 191 & 32.46 & 5.00 & & \\
\hline \multirow{2}{*}{ Reflective } & Male & 181 & 34.54 & 4.67 & \multirow{2}{*}{-1.457} & \multirow{2}{*}{0.146} \\
\hline & Female & 191 & 35.24 & 4.58 & & \\
\hline \multirow{2}{*}{ Theorist } & Male & 181 & 34.64 & 3.91 & \multirow{2}{*}{0.890} & \multirow{2}{*}{0.374} \\
\hline & Female & 191 & 34.24 & 4.70 & & \\
\hline \multirow{2}{*}{ Pragmatist } & Male & 181 & 34.77 & 4.04 & \multirow{2}{*}{-0.537} & \multirow{2}{*}{0.592} \\
\hline & Female & 191 & 35.01 & 4.28 & & \\
\hline
\end{tabular}

4. Comparison of Learning Styles Based on Academic Achievement

The analysis result with independent sample t-test is shown in Table 5 whereby the learning styles are compared based on the academic achievement of the students in their LIS subject. For comparison, academic achievement was divided into two categories: high achievement (Grade A and B) and low achievement (Grade C, D, and E). The result shows that 
there are significant differences in the activist $(\mathrm{t}=7.412, \mathrm{p}=$ theory for high and low achievement categories. Their o.00o), reflective $(\mathrm{t}=9.461, \mathrm{p}=0.000)$, theorist $(\mathrm{t}=$ 9.080, hypotheses Ho2a, Ho2b, Ho2c and Ho2d are not supported. $\mathrm{p}=0.000)$ and pragmatist $(\mathrm{t}=8.615, \mathrm{p}=0.000)$ learning

Table 5. Comparison of Learning Styles Based on High and Low Academic Achievement

\begin{tabular}{|c|c|c|c|c|c|c|}
\hline Style & $\begin{array}{c}\text { Academic } \\
\text { Achievement }\end{array}$ & $\mathbf{n}$ & Mean & SD & $\mathbf{t}$ & $\mathbf{p}$ \\
\hline \multirow{2}{*}{ Activist } & High & 147 & 36.72 & 3.73 & \multirow{2}{*}{7.412} & \multirow{2}{*}{0.000} \\
\hline & Low & 225 & 32.94 & 4.05 & & \\
\hline \multirow{2}{*}{ Reflective } & High & 147 & 37.39 & 3.98 & \multirow{2}{*}{9.461} & \multirow{2}{*}{0.000} \\
\hline & Low & 225 & 33.27 & 4.30 & & \\
\hline \multirow{2}{*}{ Theorist } & High & 147 & 36.99 & 3.47 & \multirow{2}{*}{9.080} & \multirow{2}{*}{0.000} \\
\hline & Low & 225 & 33.52 & 4.00 & & \\
\hline \multirow{2}{*}{ Pragmatist } & High & 147 & 34.50 & 4.20 & \multirow{2}{*}{8.615} & \multirow{2}{*}{0.000} \\
\hline & Low & 225 & 30.95 & 4.72 & & \\
\hline
\end{tabular}

5. Relationship between Learning Styles and Academic Achievement

Table 6 shows the relationship between the learning style of students with academic achievement of the students in LIS subject. The Pearson correlation analysis result showed that there are significant relationships between activist $(\mathrm{r}=$ 0.395, p = 0.00o), reflective $(r=0.476, p=0.000)$, theorist $(\mathrm{r}=0.492, \mathrm{p}=0.000)$ and pragmatist $(\mathrm{r}=0.471, \mathrm{p}=0.000)$. However, the strengths of the relationships are moderate. The highest correlation is for theorist learning style followed by reflective and the least correlation is for activist learning style. Therefore, hypotheses Ho3a, Ho3b Ho3c and Ho3d are supported.

Table 6. Learning Styles and Academic Achievement

\begin{tabular}{lll}
\hline Styles & $\mathbf{r}$ & $\mathbf{p}$ \\
\hline Activist & 0.395 & 0.000 \\
Reflective & 0.476 & 0.000 \\
Theorist & 0.492 & 0.000 \\
Pragmatist & 0.471 & 0.000 \\
\hline
\end{tabular}

\section{DISCUSSION OF RESEARCH FINDINGS}

This study showed that the students who learned the Living Integrated Skills subject are inclined to be more reflective and theorist rather than activist and pragmatist. Reflective students learn by watching rather than listening. They make an observation and are very careful when they make a decision. These students like to understand ideas and situations from different angles. Therefore, these students learn better when demonstrations are shown to them. Theorist learners according to Kolb (1984) are those who use abstractive conceptualisation. These students arrange information systematically and logically. Their thinking is based on intuition. These students excel when they are given theories and systematic analysis. They learn well when the learning environment is authoritative. Therefore, these students excel when there are case studies, theoretical reading, and exercises using reflective thinking methods.

However, these students are not inclined as pragmatic learners. Students who are pragmatist are more confident, likes talking, and always keep a high level of emotion. They are more focused on practical issues and relate their past learning with the current information. These students are creative and innovative; thus, they would thrive well in problem-based or project-based learning.

The findings showed that the higher academic achievers are pragmatist and activist learners while the lower academic achievers are more inclined towards being reflective and theorist learning styles. Based on the Kolb Model, this means that higher academic achievers are accommodators and convergent learners while the lower academic achievers are divergent and assimilator. In other words, the higher achievers are thinkers and the lower achievers are feelers (Kolb, 1984). As convergent learners, the higher achievers can solve problems and make decisions by searching for solutions to questions and problems. They are more attracted to technical tasks and problems than social or interpersonal issues. As accommodators, the higher achievers prefer hands-on learning. They use other people's 
analysis and prefer a practical, experiential approach. On the other hand, the lower achievers who are divergent learners would be people who prefer to watch than doing on their own and use imagination to solve problems. These students are more interested in people and tend to prefer working in groups. As assimilators, the lower achievers prefer to use a concise, logical approach. They need clear explanations and understand easily when the information is organised in a clear, logical format. They need written instruction that they can read and then given the time to think things through (Kolb, 1984; McLeod, 2017).

According to learning style theories, teaching methodology should be enlined with student learning style to maximise pupils learning. Hence, teachers should be considered the preferred learning style of student while creating students' learning material to improve student learning and their academic achievements. Since learning styles of students are different, therefore, it is suggested that teachers should employ different teaching techniques to obtain finest learning outcome from different types of learners. As implied from the result of data analysis, the students' learning styles are significantly related to their academic achievement. Therefore, understanding how they learn provides the teacher with the information on the learning activities that suit them best. For those with good academic achievement, the students would be more challenged and interested to learn about Living Integrated Skills using brainstorming, case studies, problem-solving, and group discussion. On the other hand, the weaker students can be motivated with learning activities involving theories application, stories, models, paired discussion, observing activities, getting feedback from others, and coaching (Honey \& Mumford, 1982). Therefore, this information enables the teacher to design a lesson plan that accommodates the learning styles of the higher achievers and the lower achievers.

This study has also shown that the preferred learning styles of the students are similar and dissimilar with past studies, adding to the inconsistencies of findings. Therefore, as mentioned by An and Carr (2017), although studies on learning styles and its association with students' academic achievement cannot be denied and in fact, has been proven from various studies in the past, and supported by the current study, yet, it can only conclude that it is important to determine the learning styles of the students to facilitate teachers in preparing the best teaching and learning environment and process for them. However, from a theoretical viewpoint, recent concern on the learning styles theory indicated that educators and researchers should be looking elsewhere to explain students' academic achievement, rather than on learning styles because the inconsistent result from past studies implied that there are more important factors than learning styles to shape one's academic achievement (An \& Carr, 2017). Furthermore, the result in this study showed that the aggregate mean of each learning styles is not far apart, implying that the students are using all four learning styles almost uniformly. According to Kolb (1984), the employment of all learning styles is good as it brings about the effective outcome for the student. Likewise, Researchers advocate that the best learning style is "to avoid depending upon any single style" (Bhagat et al., 2015, p. S59). Also Vita (2001, pp. 172) state that "the ability to select from a personal style portfolio according to the specific challenges of a situation is particularly valued in the real world of business where versatility and flexibility are considered critical personal attributes to respond effectively to the constantly changing demands". Therefore, the investigation on learning styles does provide good and relevant information to the teacher but there is a need to expand more to cover other variables to explain academic achievement.

\section{RECOMMENDATIONS}

Based on the research findings, it was shown that learning styles are significantly related to academic achievement. The teaching of Living Integrated Skills is based on both theory and practical, with more emphasis on practical. Therefore, from the theoretical perspective of learning theory, the learning style should be more on pragmatism but as indicated from this study, the students are more on reflective, theorist, and pragmatist learning styles. They are less keen to apply an activist learning style. Overall, it was also shown that the aggregate mean of each learning style does not differ much. It implies that academic achievement, though undeniably is the outcome to a certain degree due to how students learn, other factors that influence how 
students learn might shed more insights to explain academic achievement. Therefore, for future studies, to investigate further on students' achievement in Living Integrated Skills subject, variables such as classroom learning environment, instructional delivery styles, and students' self-efficacy might provide more information to enlighten researchers and educators on why students are high achievers while others are not.

\section{CONCLUSION}

This study has shown that learning styles are an important consideration in determining the students' academic achievement in the Living Integrated Skills subject. Although there are no significant differences in learning styles of the male and female students, yet, there are significant differences based on students' academic achievement. Furthermore, the learning styles of the higher academic achievers differ from the lower academic achievers whereby those with better grades are pragmatists and activists while those weaker ones are theorists and reflective. Familiarity with learning styles and teaching preferences of students has not been fully exploited in the development of teaching, though, the teacher can carefully select and carry out teaching and learning activities that best suit students. Thus, teachers and study program developer need to be aware that different factors exist and that variation determine the preference for alternative approaches and learning outcome. By identifying learning preferences of the student, instructors can develop effective learning programs, activities and environments. Therefore, overall, this study was able to determine which learning styles are dominantly based on the students' academic achievement. The knowledge benefits not only the teacher to facilitate their teaching plans but also to the students in developing a metacognitive of how they learn the best.

\section{REFERENCES}

Akhlaghi, N, Mirkazemi, H, Jafarzade, M \& Akhlaghi, N 2018, 'Does learning style preferences influence academic performance among dental students in Isfahan, Iran?', Journal of Educational Evaluation for Health Professions, vol. 15 , no. 8, pp. 1-6.

Allport, GW 1937, Personality: a psychological interpretation, Holt and Co, New York, USA.

An, D \& Carr, M 2017, 'Learning styles theory fails to explain learning and achievement: Recommendations for alternative approaches', Personality and Individual Differences, vol. 116, pp. 410-416.

Ang, SL, Abdul Basit \& Zubair, H 2017, 'Does learning style impact student academic performance?', International Journal of Education, Learning and Training, vol. 2, no. 2, pp. 1-13.

Awang, H, Abd Samad, N, Mohd Faiz, NS, Roddin, R \& Kankia, JD 2017, 'Relationship between the learning styles preferences and academic achievement', International Research and Innovation Summit, IOP Conference Series: Materials Science and Engineering, Malaysia.

Bell, MJ 2018, Define academic performance, viewed 11 November 2018 ,

< http://www.ehow.com/about 4740750 defineacademic-performance.html $>$.
Bhagat, A, Vyas, R \& Singh, T 2015, 'Students awareness of learning styles and their perceptions to a mixed method approach for learning', International Journal of Applied and Basic Medical Research, vol. 5, no. Suppl 1, pp. S58S65.

Boholano, HB 2017, 'Smart social networking: 21st century teaching and learning skills', Research in Pedagogy, vol. 7, no. 1, pp. 21-29.

Chermahini, SA, Ghanbari, A \& Talab, MG 2013, 'Learning styles and academic performance of students in english as a second-language class in Iran', Bulgarian Journal of Science and Education Policy, vol. 7, no. 2, pp. 322-333.

Damavandi, AJ, Mahyuddin, R, Elias, H, Mohd Daud, S \& Shabani, J 2011, 'Academic achievement of students with different learning styles', International Journal of Psychological Studies, vol. 3, no. 2, pp. 186-192.

Davrajoo, E \& Letchumanan, E 2019, 'School improvement specialist coach plus (SISC+) programme: Impact on teachers' pedagogical skills and students' performance in mathematics classroom', ASM Science Journal, vol. 12, no. 1, pp. 137-149.

Dinham, J, Choy, SC, Williams, P \& Yim, JSC 2020, 'Effective teaching and the role of reflective practices in the Malaysian and Australian education systems: A scoping 
review', Asia-Pacific Journal of Teacher Education. doi: 10.1080/1359866X.2020.1824267.

Dobson, JL 2010, 'A comparison between learning style preferences and sex, status, and course performance', Advances in Physiology Education, vol. 34, no. 4, pp. 197204.

Duff, A \& Duffy, T 2002, 'Psychometric properties of Honey and Mumford's Learning Styles Questionnaire (LSQ)', Personality and Individual Differences, vol. 33, no. 1, pp. 147-163.

Dunn, R, Burke, K \& Whitely, J 2000, What do you know about learning styles? A guide for parents for gifted children, viewed 11 November 2018, <http://www. Nagc. Org/ Publications/ parenting/ styles.html>.

Elias, E, Sarju, H, Zainudin, M, Zuhaili, I, Kamarudin, S \& Yahaya, A 2012, 'Hubungan antara gaya pembelajaran dengan pencapaian akademik pelajar tingkatan 3 sekolah menengah teknik kemahiran hidup bersepadu johor bahru', Journal of Educational Psychology \& Counseling, vol. 5, pp. 58-70.

Engel, AM 2018, 'Literature review of student characteristics and performance in an accounting course', Community College Journal of Research and Practice, vol. 42, no. 10, pp. 748-751.

Fadzil, MR, Suhaida, AK \& Ibrahim, MN 2017, 'Tahap kemahiran dan kecenderungan pemikiran kritis murid tingkatan dua dalam mata pelajaran Kemahiran Hidup Bersepadu (KHB) di negeri Kedan dan hubungannya', Asia Pacific Journal of Educators and Education, vol. 32, pp. 45-60.

Felder, RM \& Silverman, LK 1988, 'Learning styles and teaching styles in engineering education', Engineering Education, vol. 78, no. 7, pp. 674-681.

Fırat, EA, Köksal, MS \& Bahşi, A 2021, 'Effects of technology-enhanced constructivist learning on science achievement of students with different cognitive styles', Education and Information Technologies. doi: 10.1007/s10639-021-10427-0.

Fox N, Hunn A \& Mathers N 2007, Sampling and sample size calculation, the National Institutes for Health Research, East Midlands/Yorkshire \& the Humber.

Hamid, MAG, Awang, MM, Alias, J \& Shahdan, MA 2019, 'The relationship of students learning styles and historical thinking', Religación, vol. 4, pp. 121-128.

Hargadon, S 2010, Learning style theory versus sustained hard work, viewed 11 November 2018,
$<$ www.stevehargadon.com/2010/learning stylestheoryversus-sustained.html>.

Hartley, J 1998, Learning and studying: A research perspective, Routledge, London.

Hernandez, JE, Vasan, N, Huff, S \& Melovitz-Vasan, C 2020, 'Learning styles/preferences among medical students: Kinesthetic learner's multimodal approach to learning anatomy', Medical Science Educator, vol. 30, no. 4, pp. 1633-1638.

Homayoni, A \& Abdolahi, M 2003, 'Investigating correlation between learning styles and cognitive styles and their roles in academic achievement of students', Journal of Psychology, vol. 2, pp. 179-197.

Honey, P \& Mumford, A 1992, The manual of learning style, British Library Document Supply Centre, UK.

Honicke, T, Broadbent, J \& Fuller-Tyszkiewicz, M 2020, 'Learner self-efficacy, goal orientation, and academic achievement: exploring mediating and moderating relationships', Higher Education Research \& Development, vol. 39, no. 4, pp. 689-703.

Isa, NSM, Omar, N, Fatzel, FHM, Ghazali, ZM \& Anas, N 2021, 'The relationship between students' learning styles and academic performance: Final year accounting students', EDUCATUM Journal of Social Sciences, vol. 7, no. 1, pp. 1-9.

Jilardi DA, Mahyuddin, R, Elias, H, Daud, SM \& Shabani, J 2011, 'Academic achievement of students with different learning styles', International Journal of Psychological Studies, vol. 3, no. 2, pp. 186-192.

Karatas, E \& Yalin, HI 2021, 'The impact of matching learning-teaching styles on students' academic achievement', Eurasian Journal of Educational Research, vol. 92, pp. 377-402.

Kimani, GN, Kara, AM \& Njagi, LW 2013, 'Teachers' factors influencing students' academic achievement in secondary schools in Nyandarua County, Kenya', International Journal Of Education And Research, vol. 1, no. 3, pp. 1-14.

Kolb, DA 1984, Experiential learning: Experience as the source of learning and development, Prentice Hall Englewood Cliffs, NJ.

Kon, CM, Abdullah, MR \& Mohd Ibrahim, N 2012, 'Teachers' understanding and practice towards thematic approach in teaching integrated living skills (ILS) in Malaysia', International Journal of Humanities and Social Science, vol. 2, no. 23, pp. 273-281.

Kpolovie, PJ, Joe, AI \& Okoto, T 2014, 'Academic achievement prediction: Role of interest in learning and 
attitude towards school', International Journal of Humanities Social Sciences and Education (IJHSSE), vol. 1, no. 11, pp. 73-100.

Kruk, M \& Zawodniak, J 2019, 'On the possible interactions of varied EFL activities and learning styles with EFL students' motivational changes', Innovation in Language Learning and Teaching, vol. 13, no. 2, pp. 178-193.

Kumar, JA, Rajamanickam, S \& Osman, S 2020, 'Exploring the use of mobile apps for learning: A case study on final year engineering undergraduates in Malaysia', ASM Science Journal, vol. 13, no. 3, pp. 63-67.

Lynch, TG, Woelfl, NN, Steele, DJ \& Hanssen, CS 1998, 'Learning style influences students' examination performance', The American Journal of Surgery, vol. 176, pp. 62-66.

Maya, J, Luesia, JF \& Pérez-Padilla, J 2021, 'The relationship between learning styles and academic performance: consistency among multiple assessment methods in psychology and education students', Sustainability, vol. 13, no. 6, pp. 1-18.

McLeod, SA 2017, Kolb-learning styles, viewed 11 November 2018, < $\quad$ https://www.simplypsychology.org/learningkolb.html>.

Ministry of Education 2002, Sukatan pelajaran kemahiran hidup bersepadu, kuala lumpur: Curriculum development centre, Kementerian Pendidikan Malaysia.

Ministry of Education 2013, Malaysian Education Development Plan 2013-2025, Kuala Lumpur: Ministry of Education, Malaysia.

Mphale, LM \& Mhlauli, MB 2014, 'An investigation on students' academic performance for junior secondary schools in Botswana', European Journal of Educational Research, vol. 3. no, 3, pp. 111-127.

Ng, SF, Zakaria, R, See, ML \& Confessore, GJ 2014, 'A study of time uses and academic achievement among secondary school students in the state of Kelantan, Malaysia', International Journal of Adolescence and Youth, vol. 21, no. 4, pp. 433-448.

Ong, LC, Chandran, V, Lim, YY, Chen, AH \& Poh, BK 2010, 'Factors associated with poor academic achievement among urban primary school children in Malaysia', Singapore Medical Journal, vol. 51, no. 3, pp. 247-252.

Pashler, H, McDaniel, M, Rohrer, D \& Bjork, R 2008, 'Learning styles: Concepts and evidence', Psychological Science in the Public Interest, vol. 9, no. 3, pp. 105-119.

Payaprom, S \& Payaprom, Y 2020, 'Identifying learning styles of language learners: A useful step in moving towards the learner-centred approach', Dil ve Dilbilimi Çalışmaları Dergisi, vol. 16, no. 1, pp. 59-72.

Rahmanpur, M, Palezeyan, F \& Zamane, B 2008, 'Compare learning styles of students who studied engineering with students who studied humanity science in university', MD dissertation, Isfahan University, Isfahan, Iran.

Renganathan, S 2021, 'English language education in rural schools in Malaysia: a systematic review of research', Educational Review. doi: 10.1080/00131911.2021.1931041.

Riding, RJ \& Cheema, I 1991, 'Cognitive styles: an overview and integration', Educational Psychology, vol. 11, pp. 193215.

Singh, JKN \& Jamil, H 2021, 'International education and meaningful contributions to society: Exploration of postgraduate international students' perspectives studying in a Malaysian research university', International Journal of Educational Development, vol. 81, pp. 102331. doi: 10.1016/j.ijedudev.2020.102331

Srivastava, DK \& Shah, H 2021, 'Do learning styles of undergraduate and postgraduate students in B-schools differ? Insights and implications', Journal of Education for Business. doi: 10.1080/08832323.2021.1910114.

Tella, A \& Adeniyi, O 2009, 'Locus of control, interest in schooling, self-efficacy, and academic achievement', Cypriot Journal of Educational Sciences, vol. 4, no. 3, pp. 168-182.

Vita, GD 2001, 'Learning styles, culture and inclusive instruction in the multicultural classroom: A business and management perspective', Innovations in Education and Teaching International, vol. 38, no. 2, pp. 165-174.

Warner, S \& Kaur, A 2017, 'The perceptions of teachers and students on a 21st Century mathematics instructional model', International Electronic Journal of Mathematics Education, vol. 12, no. 2, pp. 193-215.

Yilmaz, M \& Orhan, F 2010, 'High school students' educational usage of Internet and their learning approaches', World Journal on Educational Technology, vol. 2, no. 2, pp. 100-112.

Yuksel, M \& Geban, O 2014, 'A study of the prediction of academic achievement in the Chemistry course', Education and Science, vol. 39, no. 173, pp. 354-365.

Zainuddin, MZ, Mohamad, NS, Asillam, MF, Mastor, MZS, Hashim, MH \& Radzi, ZM 2019, 'Space Science Education in Malaysia: A review based on performance improvement framework in complex systems', ASM Science Journal, vol. 12, no. 2 , pp. 172-182. 